\title{
SIMPLIFY CHARTS FOR THE DESIGN OF VERTICAL FORMWORK SYSTEMS
}

\section{K. M. Shawki}

Assistant Professor, construction and building engineering Dept. Collage of Engineering and Technology Arab Academy for Science, Technology and Martine Transport-Alexandria-Egypt. kshawki.eng@gmail.com

(Received August 16, 2009 Accepted September 13, 2009).

This paper presents simplify charts for the design of traditional wall formwork systems. The first step is to determine the pressure due to fresh concrete using the cement type, concrete weight, rate of placing and the temperature. The second step is to determine the safe distance between studs using plywood thicknesses 19 or 22 or $25 \mathrm{~mm}$.The third step is to determine the distance between walls using studs of $50 * 100 \mathrm{~mm}(2 * 4$ in) or $50 * 125 \mathrm{~mm}(2 * 5$ in) or $50 * 150 \mathrm{~mm}(2 * 6$ in) lumber. Finally the safe distance between ties is determined using wale section of double $50 * 100 \mathrm{~mm}(2 * 4$ in) or $50 * 125 \mathrm{~mm}(2 * 5$ in) lumber.

KEYWORDS: wall formwork, construction.

\begin{tabular}{|c|c|c|c|}
\hline \multicolumn{4}{|c|}{ NOTATIONS } \\
\hline$A$ & area of section $\left(\mathrm{mm}^{2}\right)^{*}$ & $F_{v}$ & allowable unit stress in horizontal \\
\hline$b$ & width of member (mm) & & shear $(\mathrm{kPa})$ \\
\hline$d$ & depth of member (mm) & $f_{c}$ & actual unit stress in compression \\
\hline$E$ & modulus of elasticity (kPa) & & parallel to grain $(\mathrm{kPa})$ \\
\hline$E I$ & $\begin{array}{l}\text { plywood stiffness capacity }(\mathrm{kPa} \\
\left.\mathrm{mm}^{4} / \mathrm{m}\right)\end{array}$ & $F_{c l}$ & $\begin{array}{l}\text { actual unit stress in compression } \\
\text { perpendicular to grain }(\mathrm{kPa})\end{array}$ \\
\hline \multirow[t]{2}{*}{$F_{b}$} & allowable unit stress in bending & $f_{t}$ & actual unit stress in tension $(\mathrm{kPa})$ \\
\hline & $(\mathrm{kPa})$ & $I$ & moment of inertia $\left(\mathrm{mm}^{4}\right)^{*}$ \\
\hline$F_{b} K S$ & $\begin{array}{l}\text { plywood section capacity in } \\
\text { bending }(\mathrm{Nmm} / \mathrm{m})\end{array}$ & $l$ & $\begin{array}{l}\text { length of span, center to center of } \\
\text { supports (mm) }\end{array}$ \\
\hline$F_{c}$ & $\begin{array}{l}\text { allowable unit stress in compress- } \\
\text { ion parallel to grain }(\mathrm{kPa})\end{array}$ & $P$ & $\begin{array}{l}\text { applied force (compression or } \\
\text { tension) (lb) }\end{array}$ \\
\hline \multirow[t]{3}{*}{$F_{c l}$} & allowable unit stress in & $S$ & section modulus $\left(\mathrm{mm}^{3}\right)^{*}$ \\
\hline & compression perpendicular to & $w$ & uniform load per foot of span \\
\hline & & $\Delta$ & deflection $(\mathrm{mm})$ \\
\hline
\end{tabular}

For a rectangular member: $\mathrm{A}=\mathrm{bd}, \mathrm{S}=\mathrm{bd}^{2} / 6, \mathrm{I}=\mathrm{bd}^{3} / 12$.

\section{INTRODUCTION}

An inherent property of concrete is that it can be transformed into any shape. The wet mixture is placed in forms constructed of wood, metal or other suitable material to harden or set. The form must be assembled with quality workmanship, holding to close 
dimensional tolerances. Formwork should be strong enough to support the concrete's weight and rigid enough to maintain its position and appearance. In addition, formwork must be tight enough to prevent the water seepage and designed to permit ready removal. Because the formwork for a concrete structure constitutes a considerable item in the cost of the completed structure, particular care should be exercised in its design. It is desirable to maintain a repetition of identical units so that the forms may be removed and reused at other locations with a minimum amount of labor.

Formwork holds concrete until it sets, produces the desired shapes, and develops a desired surface finish. Forms also protect concrete, aid in curing, and support any reinforcing bars or conduit embedded within the concrete. Because formwork can represent up to one-third of a concrete structure's total cost, this phase of a project is very important. The nature of the structure, availability of equipment and form materials, anticipated reuse of the forms, and familiarity with construction methods all influence the formwork design. To design forms, the strength of the forming materials and the loads they support you must know. The concrete's final shape, dimensions, and surface finish must be considered.

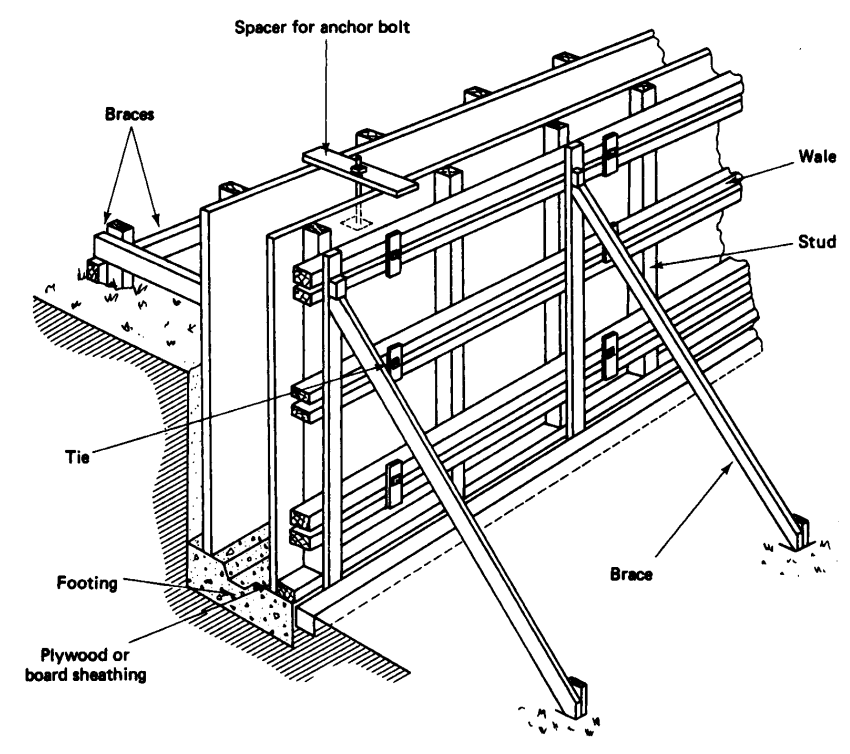

Fig (1) Traditional wall formwork system

\section{TRADITIONAL DESIGN CALCULATIONS FOR WALL FORMWORK SYSTEMS}

\section{STEP 1: Determination of pressure due to fresh concrete}

The first step is to determine the pressure due to fresh concrete using the concrete unit $(\gamma)$ weight, cement type, rate of placing $(\mathrm{R})$ and the temperature $(\mathrm{T})$.using the formula shown in Table (1): 
Table (1) Lateral pressure due to fresh concrete on wall formwork

\begin{tabular}{|c|l|c|}
\hline \multicolumn{1}{|c|}{$\mathbf{R}<\mathbf{2 . 1} \mathbf{~ m} / \mathbf{h r}$} & \multicolumn{1}{|c|}{$\mathbf{2 . 1} \leq \mathbf{R} \leq \mathbf{4 . 6} \mathbf{~ m} / \mathbf{h r}$} & $\begin{array}{c}\mathbf{R}>\mathbf{4 . 6} \\
\mathbf{m} / \mathbf{h r}\end{array}$ \\
\hline $\begin{array}{l}\text { (1) } \mathrm{P}=\mathrm{C}_{\mathrm{W}} \mathrm{C}_{\mathrm{C}}(7.2 \\
\left.+\frac{785 R}{T+18}\right) \ldots \ldots \ldots \ldots \ldots . . .(1)\end{array}$ & $\begin{array}{l}\mathrm{P}=\gamma \mathrm{h} \\
\left.+\frac{1154}{T+18}+\frac{244 R}{T+18}\right) \ldots \ldots \ldots . . .(2)\end{array}$ \\
(2) $\mathrm{P}_{\max }=\gamma \mathrm{h}=\mathrm{C}_{\mathrm{W}} \mathrm{C}_{\mathrm{C}}(7.2$ & \\
(3) $\mathrm{P}_{\min }=28.7 \mathrm{C}_{\mathrm{W}} \quad$ (kPa) & (2) $\mathrm{P}_{\max }=\gamma \mathrm{h}$ & \\
\hline
\end{tabular}

Where :

$\mathrm{P}=$ pressure due to fresh concrete $(\mathrm{kPa})$

$\mathrm{R}=$ rate of placing $(\mathrm{m} / \mathrm{hr})$

$\mathrm{T}=$ temperature $\left({ }^{\circ} \mathrm{C}\right)$

$\mathrm{C}_{\mathrm{w}}=$ concrete unit weight coefficient as shown in Table (2)

$\mathrm{C}_{\mathrm{c}}=$ concrete chemistry coefficient as shown in Table (3)

$\mathrm{h}=$ wall height $(\mathrm{m})$

$\gamma=$ concrete unit weight $\left(\mathrm{kg} / \mathrm{m}^{3}\right)$

Table (2) Concrete unit weight coefficient $\left(\mathrm{C}_{\mathrm{w}}\right)$

\begin{tabular}{|c|c|}
\hline$\gamma$ & $\mathbf{C w}$ \\
\hline Under $2243 \mathrm{~kg} / \mathrm{m}^{3}$ & $0.5\left(1+\frac{\gamma}{2323}\right) \quad$ but at least 0.80 \\
\hline 2243 to $2403 \mathrm{~kg} / \mathrm{m}^{3}$ & 1.0 \\
\hline Over $2403 \mathrm{~kg} / \mathrm{m}^{3}$ & $\left(\frac{\gamma}{2323}\right)$ \\
\hline
\end{tabular}

Where :

$\gamma=$ concrete unit weight $\mathrm{kg} / \mathrm{m}^{3}$

Table (3) Concrete chemistry coefficient $\left(\mathrm{C}_{\mathrm{c}}\right)$

\begin{tabular}{|c|c|}
\hline Cement Type or Blend & Cc \\
\hline Type I, II, or III without retarders & 1.0 \\
\hline Type I, II, or III with a retarders & 1.2 \\
\hline $\begin{array}{c}\text { Other blends containing less than 70\% } \\
\text { slag or 40\% fly ash without retarders }\end{array}$ & 1.2 \\
\hline $\begin{array}{c}\text { Other blends containing less than 70\% } \\
\text { slag or 40\% fly ash with a retarder }\end{array}$ & 1.4 \\
\hline $\begin{array}{c}\text { Other blends containing more than 70\% } \\
\text { slag or 40\% fly ash }\end{array}$ & 1.4 \\
\hline
\end{tabular}




\section{Step 2 Determination of safe distance between studs:}

The safe distance between studs is determined using plywood sheathing of thickness 19 or 22 or $25 \mathrm{~mm}$. The allowable stresses and section properties of such plywood is determined from the manufacture's catalog. Then the safe distance is determined to satisfy both bending (Equation1) and deflection (Equation2) for three or more spans as follows (See Appendix I for notations :

The safe distance due to bending is:

$$
l=3.16\left(\frac{F_{6} K S}{w}\right)^{1 / 2}
$$

The safe distance due to deflection $(1 / 360)$ is:

$$
l=\frac{73.8}{1000}\left(\frac{E I}{w}\right)^{1 / 3}
$$

\section{Step 3 Determination of safe distance between walls:}

The safe distance between walls is determined using the section properties of $50 * 100$ $\mathrm{mm}(2 * 4$ in), or $50 * 125 \mathrm{~mm}(2 * 5 \mathrm{in})$ or $50 * 150 \mathrm{~mm}$ ( $2 * 6$ in) cross sections. The cross sectional area, section modulus, and moment of inertia are determined for the proposed section then the adjusted allowable stress for lumber being used is determined. The safe distance between walls is determined to satisfy the bending (Equation 3) and deflection (Equation 4) for case for three or more spans as follows (See Appendix I for notations):

The safe distance due to bending is:

$$
l=\frac{40.7}{1000} d\left(\frac{F_{6} 6}{w}\right)^{1 / 2}
$$

The safe distance due to deflection $(1 / 360)$ is:

$$
l=\frac{73.8}{1000}\left(\frac{E I}{w}\right)^{1 / 3}
$$

\section{Step 4 Determination of safe distance between ties:}

The safe distance between ties is determined using the section properties of double walls of $50 * 100 \mathrm{~mm}(2 * 4$ in) o $50 * 125 \mathrm{~mm}(2 * 5$ in) cross sections. The cross sectional area , section modulus , and moment of inertia is determined for the proposed section then the adjusted allowable stress for lumber being used is determined. The safe distance between ties is determined to satisfy the bending from Equation (3) and deflection from Equation (4) for case for three or more spans.

\section{HOW TO USE THE SIMPLIFIED CHARTS TO DESIGN TRADITIONAL WALL FORMWORK SYSTEMS}

In order to demonstrate the design using simplified charts, a case example was performed using the following data:

Wall height $3.0 \mathrm{~m}$, rate of placing $1.5 \mathrm{~m} / \mathrm{hr}$, temperature is $27^{\circ} \mathrm{C}$, cement type I without retarders, concrete unit weight is $2403 \mathrm{~kg} / \mathrm{m}^{3}$, plywood sheathing is $25 \mathrm{~mm}$ thickness 
Class (I), studs will be $50 * 100 \mathrm{~mm}$ and walls will double $50 * 100 \mathrm{~mm}$. The use of these simplified charts is as follows:

(1) Referring to Fig. (2) to determine the pressure due to fresh concrete if rate of placing less than $2.1 \mathrm{~m} / \mathrm{hr}$, Fig.(3) if rate of placing greater or equal $2.1 \mathrm{but}$ less or equal $4.6 \mathrm{~m} / \mathrm{hr}$ and if rate of placing greater than $4.6 \mathrm{~m} / \mathrm{hr}$ the pressure will be $\gamma \mathrm{h}$. For rate of placing equal $1.5 \mathrm{~m} / \mathrm{hr}$ entering at the bottom of chart (Fig (2) point A) to the line representing the expected concrete temperature, the pressure due to fresh concrete is in the vertical axis (point B) .

(2) Referring to Fig (4) find the safe distance between studs is determine by drawing a vertical line from point $\mathrm{C}$ across to the curve for the desired plywood thickness $25 \mathrm{~mm}$ (point D) (N.B. point D is the minimum distance resulting from bending and deflection.

(3) Referring to Figs $(5,6,7)$ find distance between walls .Use Fig (5) if the studs will be $50 * 100 \mathrm{~mm}(2 * 4 \mathrm{in}), \mathrm{Fig}(6)$ if the studs will be $50 * 125 \mathrm{~mm}(2 * 5 \mathrm{in})$, and Fig(7) if the stud will be $50 * 150 \mathrm{~mm}(2 * 6 \mathrm{in})$.) .In our case the studs will be $50 * 100 \mathrm{~mm}$ so, Fig (5) will be used. From point E draw a vertical line (distance between studs ) to intersect the desired pressure (point F).(N.B. the distance in this curve is the minimum distance resulting from bending and deflection point $\mathrm{G}$ )

(4) Referring to Figs $(7,8)$ find distance between metal ties. Use Fig (7) if the walls will be double $50 * 100 \mathrm{~mm}(2 * 4 \mathrm{in}), \mathrm{Fig}(8)$ if the walls will be double $50 * 125 \mathrm{~mm}(2 * 5 \mathrm{in})$. In our case the walls will be double $50 * 100 \mathrm{~mm}$ so Fig (7) will be used. From point $\mathrm{H}$ draw a vertical line (distance between walls) to intersect the desired pressure (point I).(N.B. the distance in this curve is the minimum distance resulting from bending and deflection point $(\mathrm{J})$.

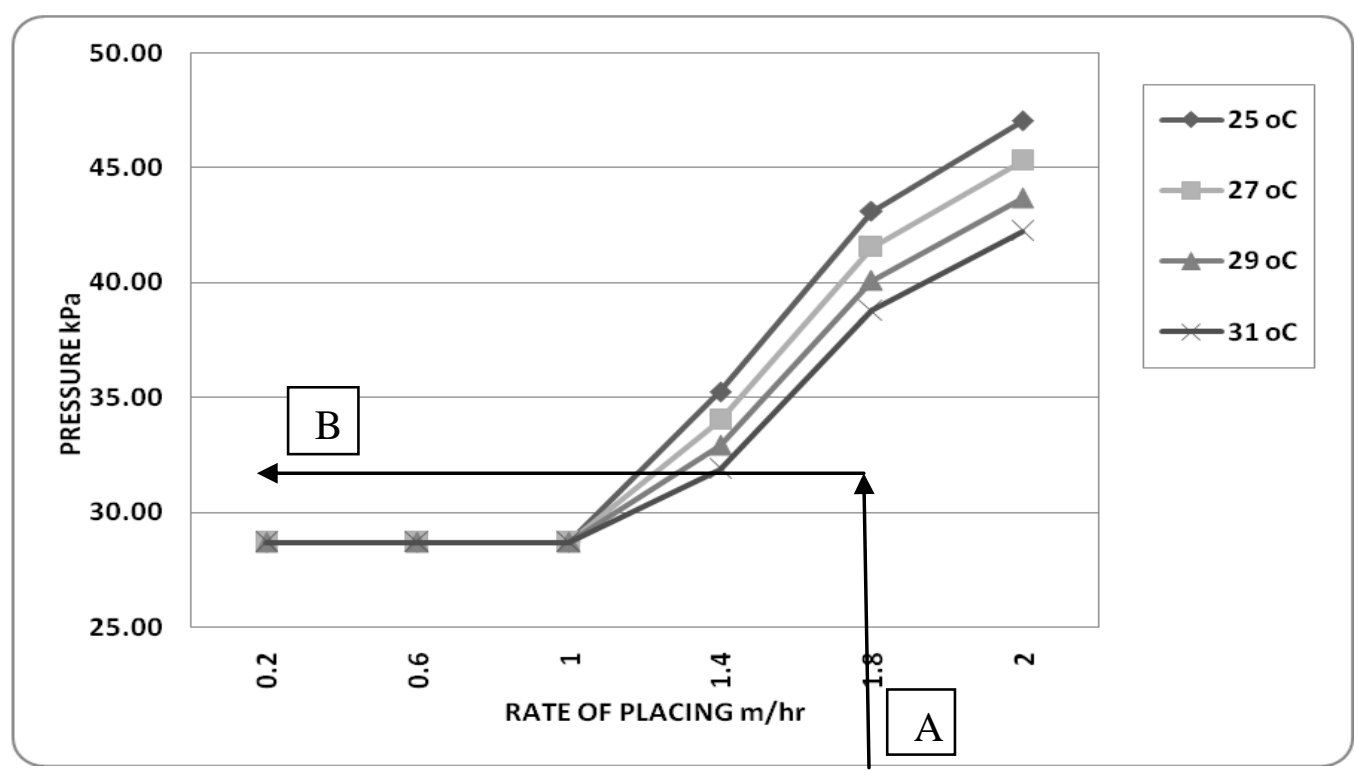

Fig. (2) Determination of pressure due to fresh concrete for $\mathrm{R}<2.1 \mathrm{~m} / \mathrm{hr}$ 


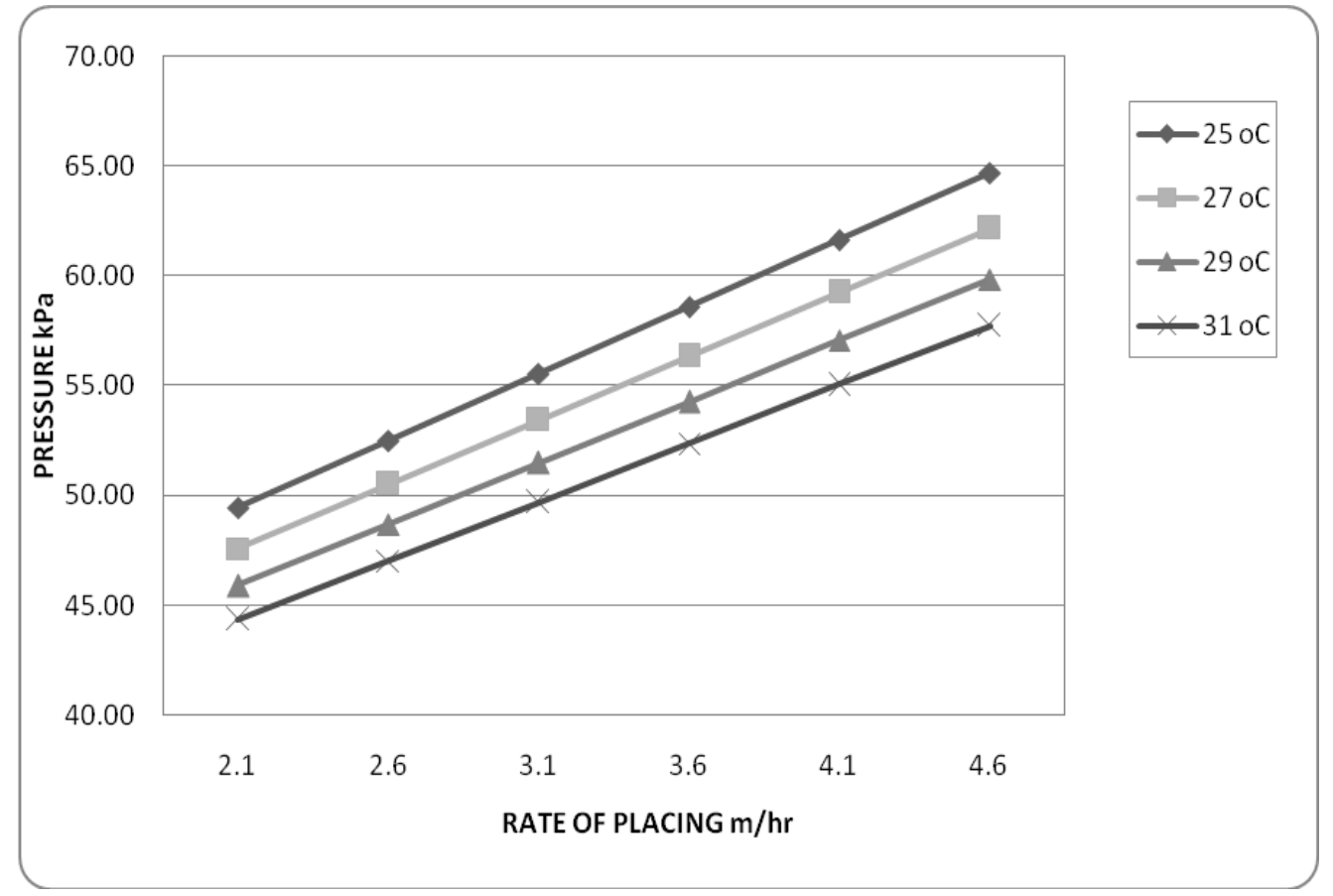

Fig. (3) Determination of pressure due to fresh concrete for $2.1 \leq R \leq 4.6 \mathrm{~m} / \mathrm{hr}$

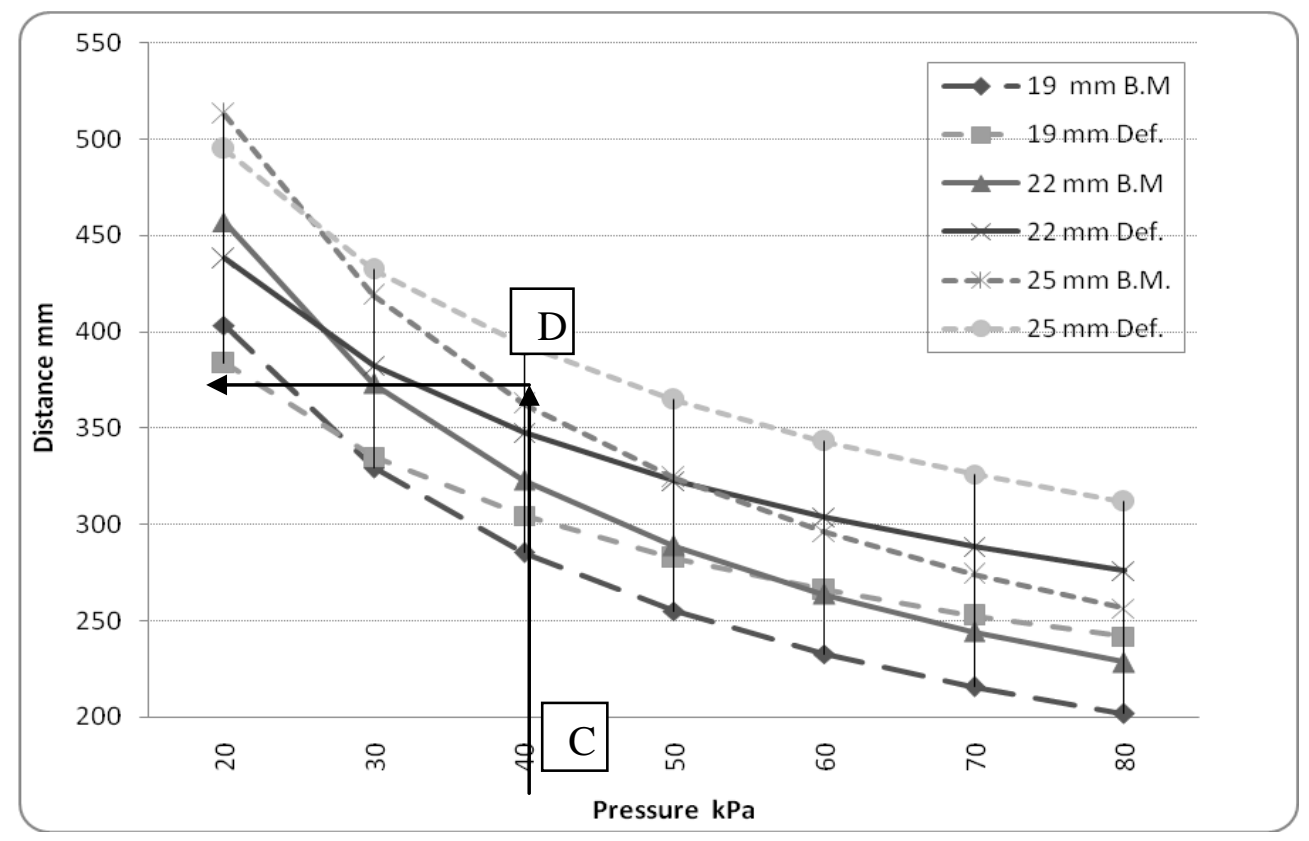

Fig. (4) Determination of safe distance between studs 


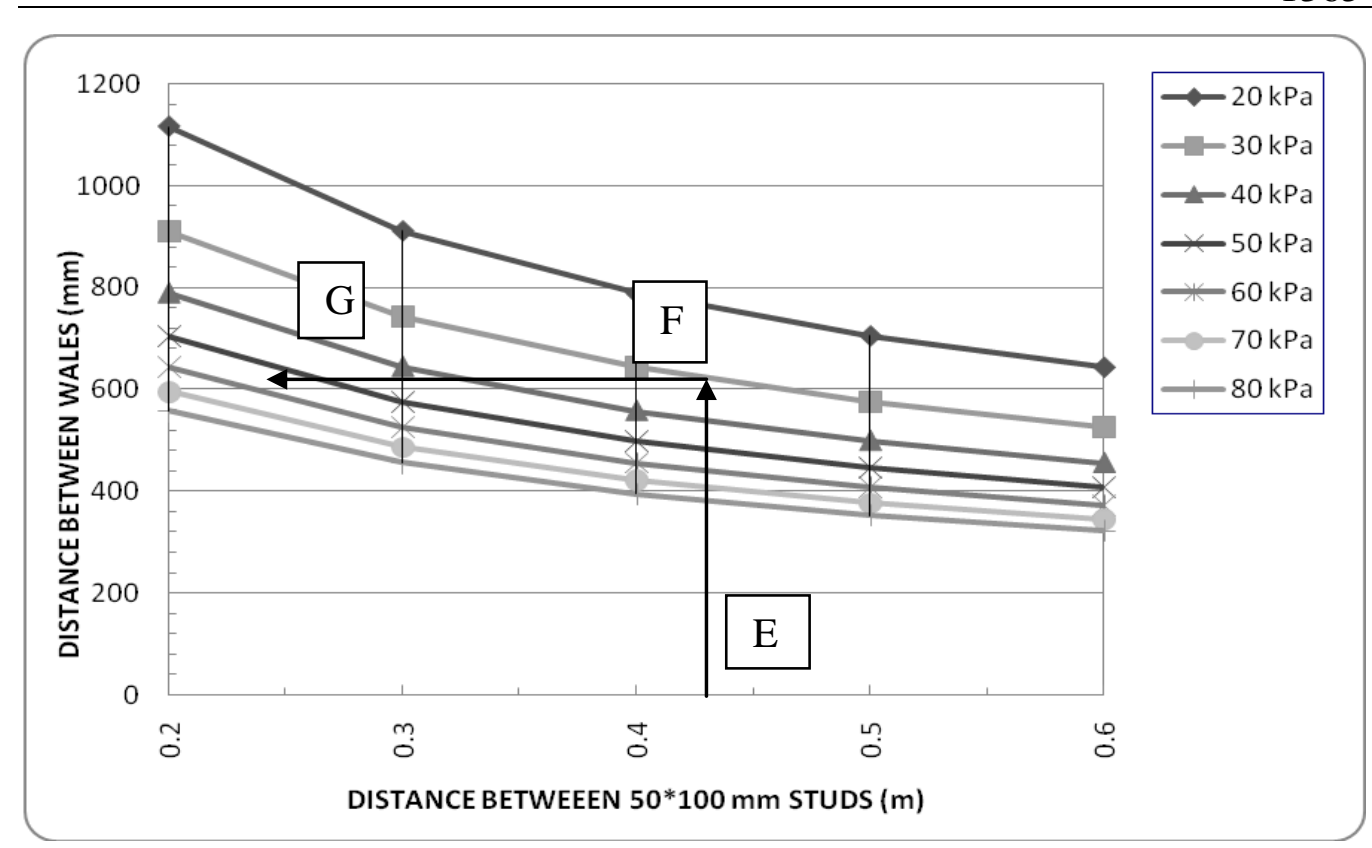

Fig. (5) Determination of safe distance between walls (50*100 studs)

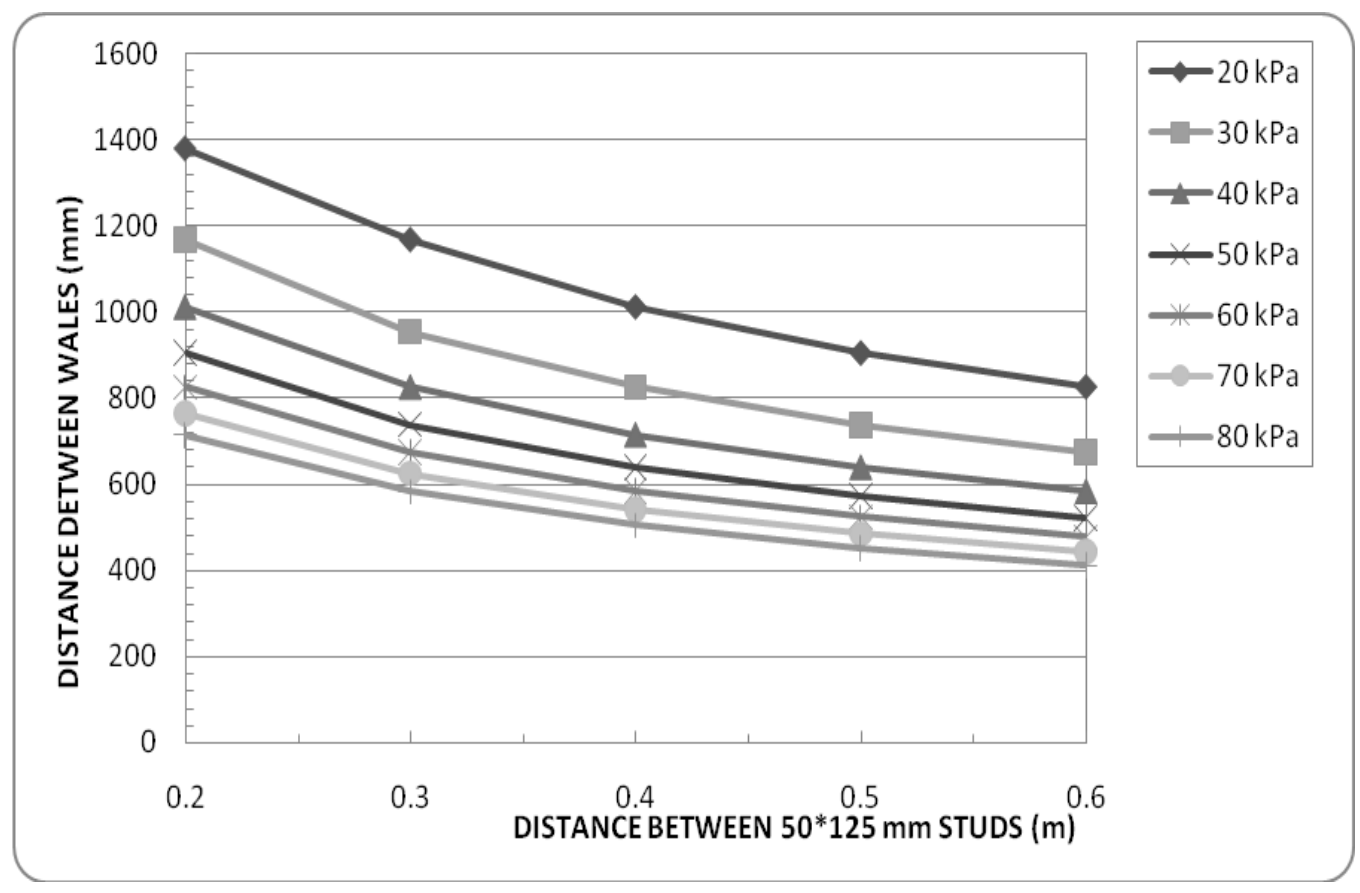

Fig. (6) Determination of safe distance between walls (50*125 mm studs) 


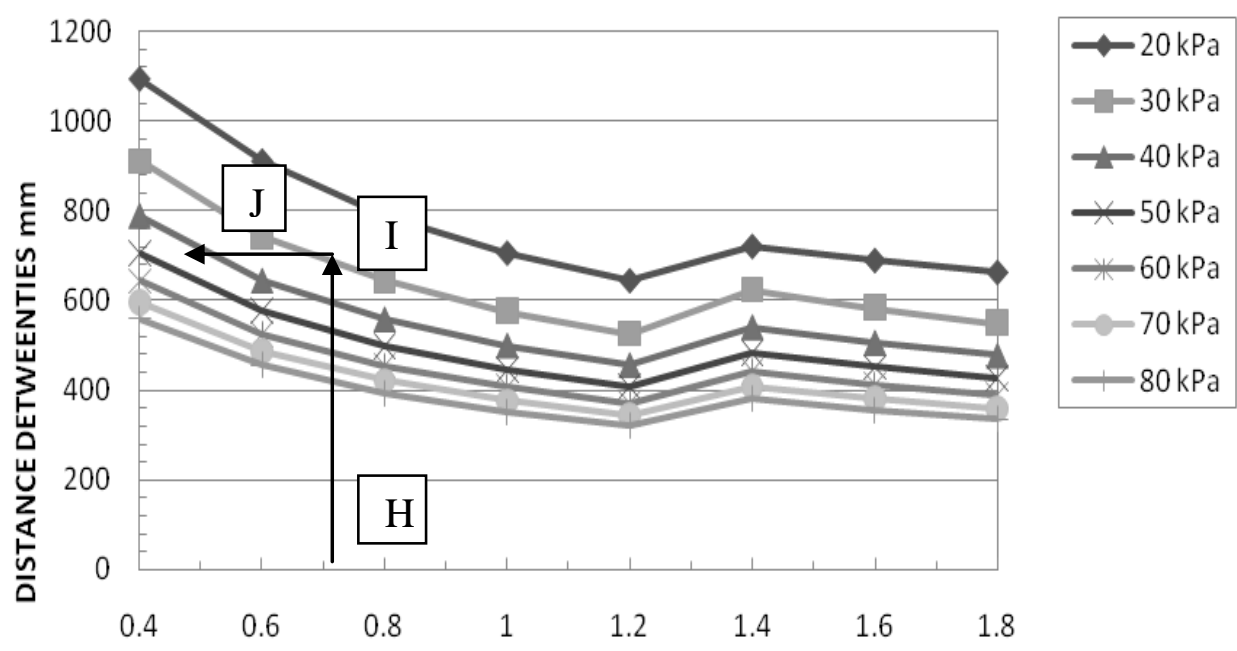

DISTANCE BETWEEN 50*100 STUDS (m)

Fig. (7) Determination of safe distance between ties using double $50 * 100 \mathrm{~mm}(2 * 4$ in ) walls

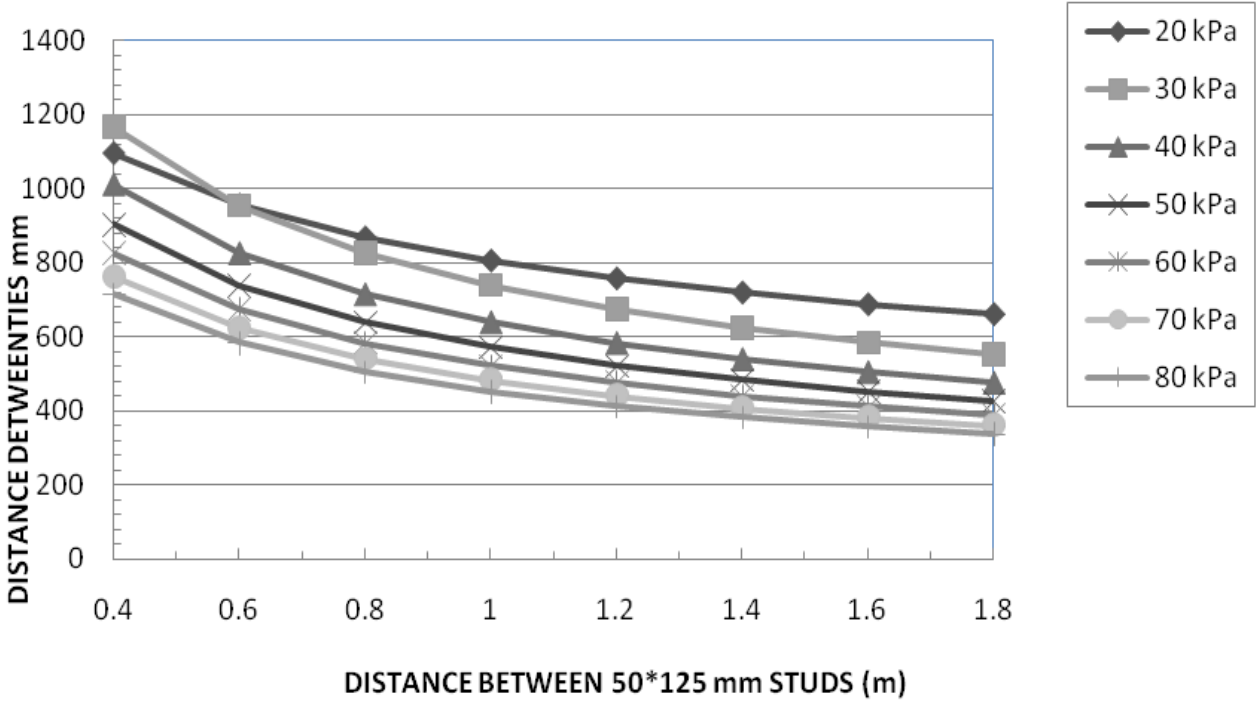

Fig.(8) Determination of safe distance between ties using double $50 * 125 \mathrm{~mm}(2 * 5$ in $)$ walls 


\section{CONCLUSIONS}

Design charts like the one presented here reduce most calculations to simple arithmetic. The user can easily select or check sheathing, studs, and walls without tedious calculations. It is hoped that this will help the craftsman or the small contractors to build forms with some engineering logic and not by empirical guesses.

\section{REFERENCES}

[1] Hued, M. K., Formwork for Concrete, $4^{\text {th }}$ ed., American Concrete Institute, Detroit, MI.

[2] Sommers, Pau H. "Charts Aid in Design of Horizontal Formwork ", Concrete construction, July 1984, p. 648.

[3] Sommers, Pau H "Charts Aid in Design of Vertical Formwork ", Concrete construction, July 1984, p. 392.

[4] S.W.Nunnally "Managing Construction Equipment" second edition. 2009. Prentice - Hall, Inc.

[5] Peurifoy/Schexanyder "Construction Planning, Equipment, and Methods" McGraw-Hill sixth edition 2002.

[6] Frank Harris "Modern Construction and Ground Engineering Equipment and Methods" LONGMAN 1994.

\section{منحنيات مبسطة لتصميم انظمة الثدات الراسية}

يتتـاول هذا البحث طريقـة مبسطة لتصـم الثـدات الراسية الثقليديـة للحوائط مـن الخشب ب باستخدام

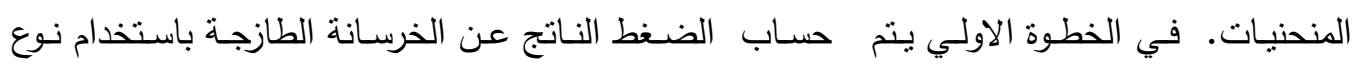

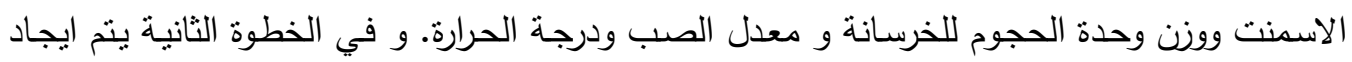

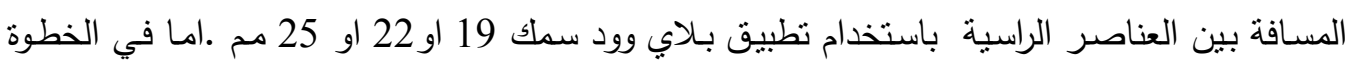

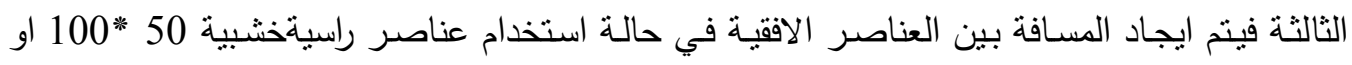

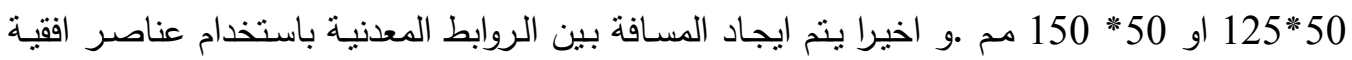
خشبية مزدوجة عبارة عن قطاعين بابعاد 50*100 او 50* 125 مم . 